Egyptian Journal of Aquatic Biology \& Fisheries

Zoology Department, Faculty of Science,

Ain Shams University, Cairo, Egypt.

ISSN $1110-6131$

Vol. 23(4): 639 - 657 (2019)

www.ejabf.journals.ekb.eg

\title{
Biological treatment of ammonia using biofloc system for Oreochromis niloticus fish
}

\author{
Nasr M. Ahmed*, Nasser S. Flefil, Safaa I. Tayel, Soaad A. Mahmoud and \\ Abdel-Ghany Soliman \\ National Institute of Oceanography and Fisheries, Egypt \\ *Corresponding author: nasrahmednas@yahoo.com
}

\section{ARTICLE INFO \\ Article History: \\ Received: Oct. 9, 2019 \\ Accepted: Oct. 30, 2019 \\ Online: Nov. 2019}

Keywords:

Biofloc system

Oreochromis niloticus

Phytoplankton

Histopathology

Hematology

Nitrification

Ammonia

\section{ABSTRACT}

This study aimed to estimate the effect of biofloc technology (BFT) implementation on water quality and production performance of Nile tilapia (Oreochromis niloticus) using different concentrations of ammonia and attempt for treatment of excess ammonia by biofloc system with fixed temperature, $\mathrm{pH}$ and dissolved oxygen. The improvement and organization of phytoplankton communities in each case was monitored. The hematological and histological alterations of studied fish were also noticeable. Phytoplankton communities developed in this study were dominated by Chlorophyceae followed by Cyanophyceae, Bacillariophyceae and Euglenophyceae.

The collected fish were divided into five groups; the first group was left as the control, the second and third groups were supplemented with ammonia $\left(0.25 \mathrm{LC}_{50}, 0.50 \mathrm{LC}_{50}\right)$ and the fourth and fifth groups were cultured under biofloc system $\left(0.25 \mathrm{LC}_{50}, 0.50 \mathrm{LC}_{50}\right)$. The results revealed that the phytoplankton used in the biofloc system gradually converted ammonia into nitrate. Hematological studies revealed that the studied biochemical parameters of blood obtained from fish cultured under biofloc system were very close to that of the control. Also, histological studies showed that fish cultured under biofloc system appeared close to recovery and similar to that obtained from control. In conclusion, phytoplankton in the biofloc system improves water quality and production performance of cultured fish by enhancing nitrification and transformation, of ammonia (toxic) into nitrate (non-toxic).

\section{INTRODUCTION}

Biofloc technology (BFT) is an aquaculture system which focused on a more efficient use of nutrient input with limited or zero water exchange (Widanarni et al., 2012). Phytoplankton is a source of characteristic feed for fish cultivation in the pond. Phytoplankton yield increases by the increasing nutrient content in the pond. Feed and metabolic waste is the wellsprings of nutrient for phytoplankton growth (Arifin et al., 2018). The increasing nutrients entering to the pond affect the phytoplankton composition and its density (Case et al., 2008). Algae need nitrate as a source of nutrients that are absorbed from the water and therefore the concentration of nitrate in the water media was lower (Ebeling et al., 2006). One of the most important groups in biofloc systems is phytoplankton, microalgae use ammonia and compounds as nitrite and nitrate for construction of proteins and they also provide oxygen during day time (Moss, 2002). 
Microalgae are able to assimilate a variety of nitrogen sources from an aquatic environment, mainly nitrates $\left(\mathrm{NO}_{3}{ }^{-}\right)$, ammonium $\left(\mathrm{NH}_{4}{ }^{+}\right)$and urea etc. $\mathrm{NH}_{4}{ }^{+}-\mathrm{N}$ is the most preferred nitrogen source for microalgae growth since it is in a reduced state and low energy is required for its metabolic uptake by microalgae (active transmission at the plasma membrane), which also makes it energetically very efficient source (PerezGarcia et al., 2011).

BFT systems depend on the living microorganisms in the biofloc (composed of organic matter and microbial biomass) maintained in the water column to aid in ammonia removal via phytoplankton, bacterial uptake and bacterial oxidation of ammonia- $\mathrm{N}\left(\mathrm{NH}_{3}-\mathrm{N}\right)$ to nitrite- $\mathrm{N}\left(\mathrm{NO}_{2}-\mathrm{N}\right)$ and then subsequent oxidation of $\mathrm{NO}_{2}-\mathrm{N}$ to nitrate- $\mathrm{N}\left(\mathrm{NO}_{3}-\mathrm{N}\right)$ non-toxic by nitrification (Brune et al., 2003; Ebeling et al., 2006 and Hargreaves, 2006). Therefore, these biological processes play a critical part in reducing ammonia and nitrite concentration to levels below from toxic or growthlimiting for cultured fish.

Fish is one of the most important aquatic organisms greatly affected by environmental pollution, this is reflected on function of organs. Tilapia is considered as one the most common genus of fish, widely spread throughout Africa, south America and the middle east. Fish Oreochromis niloticus is selected for our investigation because of its economic importance and representing a high percent of the total catch each year along the River Nile and the lakes. It is considered as a well marketable fish and has tolerance for a wide range of environmental condition and shows little susceptibility to diseases (Kadry et al., 2015).

Hematological and histopathological studies are considered as direct display referring to any adverse impact on fish. The most important fish organs affected by water pollution are gills, kidney, liver and spleen (Tayel et al., 2018). Blood components may be used as marker for tissue destruction, because, fish blood is sensitive to pollution-induced stress and certain changes in the blood profile may indicate changes in metabolism and biochemical processes of the organism. The increments in the ALT and AST level activities in serum could consider as indicators for liver damage (Ibrahim and Mahmoud, 2005). However, the increasing of the serum urea and creatinine may be ascribing to kidney disorders (Tayel et al., 2014).

This study was aimed to treat the negative effect of increased ammonia on hematological parameters and histological structures Oreochromis niloticus fish using biofloc system. Phytoplankton community was considered as an indicator of toxic ammonia reduction to non-toxic nitrate

\section{MATERIALS AND METHODS}

\section{Fish preparation and experiment design}

The present study was carried out at the experimental fish farm, El-Serw Station for Fish Research, Inland Water branch, National Institute of Oceanography and Fisheries. A total of 270 fish weighting from 25.0 to 30.0 grams were transported to the laboratory. Fish were acclimatized to the lab conditions for about two weeks.

The experiment was carried out in glass aquaria having volume of $50 \mathrm{~L}$ each with water depth of $25 \mathrm{~cm}$. The chemical compound used was ammonium chloride $\left(\mathrm{NH}_{4} \mathrm{Cl}\right)$.

\section{Determination of 96 hrs- $\mathrm{LC}_{50}$ of $\mathrm{NH}_{3}-\mathrm{H}$}

A total number of 120 Oreochromis niloticus fish with average body weight 27.0 \pm 3.0 grams were divided into 12 groups (10 fish/group). First group was left as a control, while, ${ }^{2} \mathrm{nd},{ }^{3} \mathrm{rd},{ }^{4}$ th, ${ }^{5}$ th, ${ }^{6}$ th, ${ }^{7}$ th, ${ }^{8}$ th, ${ }^{9}$ th, ${ }^{10}$ th, ${ }^{11}$ th and ${ }^{12 t h}$ groups were 
exposed to 20.0, 30.0, 32.0, 34.0, 36.0, 38.0, 40.0, 42.0, 44.0, 46.0 and $48.0 \mathrm{mg} / \mathrm{l}$ of $\mathrm{NH}_{3}-\mathrm{H}$, respectively.

These concentrations were selected as trails for determination of $96 \mathrm{hrs}-\mathrm{LC}_{50}$ of $\mathrm{NH}_{3}-\mathrm{H}$ concentration. Fish were observed at $12 \mathrm{hrs}$ interval up to $96 \mathrm{hrs}$. The dead fish was removed immediately up on discovery. Mortalities and survival time were recorded, and then $\mathrm{LC}_{50}$ was calculated according to the equation of Behrens and Karper (1953). The calculated $96 \mathrm{hrs}-\mathrm{LC}_{50}$ of ammonia for Oreochromis niloticus was $38.4 \mathrm{mg} / \mathrm{l}$.

\section{Effect of sub-chronic toxicity of $\mathrm{NH}_{3}-\mathrm{H}$ in Oreochromis niloticus fish:}

A total number of 150 Oreochromis niloticus with average body weight 27.0 \pm 3.0 grams were divided into 5 groups. Each group has 3 replicates (10 fishes / replicate). Ammonia was prepared to produce the required concentrations, 0.50 (19.2 $\left.\mathrm{mg} / \mathrm{l} \mathrm{NH} \mathrm{NH}_{3}-\mathrm{H}\right)$ and $0.25(9.6 \mathrm{mg} / \mathrm{l} \mathrm{NH} 3-\mathrm{H})$ of $96 \mathrm{hrs}-\mathrm{LC}_{50}$ for fish.

The experiment was conducted using 0.50 and 0.25 of 96 hrs- $\mathrm{LC}_{50}$ of $\mathrm{NH}_{3}-\mathrm{H}$ concentrations and control.

1- The first glass aquarium, control

2- The second glass aquarium, effect of sub-chronic toxicity of $\mathrm{NH}_{3}-\mathrm{H}$ on Oreochromis niloticus fish, using $0.50 \mathrm{LC}_{50}\left(19.2 \mathrm{mg} / \mathrm{l} \mathrm{NH}_{3}-\mathrm{H}\right)$.

3- The third glass aquarium, effect of sub-chronic toxicity of $\mathrm{NH}_{3}-\mathrm{H}$ on Oreochromis niloticus fish, using $0.25 \mathrm{LC}_{50}\left(9.6 \mathrm{mg} / \mathrm{l} \mathrm{NH} \mathrm{NH}_{3}-\mathrm{H}\right)$.

4- The fourth glass aquarium, $0.50 \mathrm{LC}_{50}$ with using biofloc system.

5- The fifth glass aquarium, $0.25 \mathrm{LC}_{50}$ with using biofloc system.

Three replicate units were randomly assigned to each treatment.

Using the biofloc system for the treatment process by adding molasses as a carbon source to encourage the growth of phytoplankton and zooplankton used in treatment.

Using a small compressed air pump, the water in each aquarium was aerated to maintain the oxygen concentration from 7 to $8 \mathrm{mg} / \mathrm{l}, \mathrm{pH} 7.5-8.0$ and temperature ranged between 26 to $28^{\circ} \mathrm{C}$ throughout the experiment.

Phytoplankton identifications and enumerations

Drop technique was applied for counting and identification of phytoplankton species (APHA, 2012), triplicate samples ( 2 or $5 \mu$ l) were taken and examined under inverted microscope ZEISS IM 4738, with magnification power 40 and 100x. The results of phytoplankton density were presented as number of units per liter (units/l).

Phytoplankton identification was performed according to Prescott (1978); Lee (2008) and Bellinger and Sigee (2010).

\section{Canonical Correlation Analysis:}

The relationship between the phytoplankton community and environmental factors was analyzed by canonical correlation analysis (CCA) using Canoco for Windows 4.5 soft.

\section{Fish Samples analysis:}

\section{Hematological studies:}

Blood samples were taken by severance of the caudal peduncle of the studied fish and analyzed at the same day. The samples were collected in small sterilized vials and left to clot and then centrifuged at $3000 \mathrm{rpm}$ for 10 minutes to obtain serum. Supernatant serum was obtained using micropipette (model Labystems K 33071) for biochemical studies. The biochemical analyses were measured using Kits according to the manufacture instructions. Serum glucose level was determined according to GODPAP enzymatic colorimetric method (Tietz, 1995), (Spectrum Kit). Serum total proteins level was estimated calorimetrically according to the method of Henry 
(1974), (Biorexfars Kit). Serum albumin level was measured calorimetrically according to the procedure of Doumas et al. (1971), (Vitro Scient Kit). Serum total cholesterol level was determined according to CHOD-PAP enzymatic colorimetric method (Ellefson and Caraway, 1976), (Spectrum Kit). Serum triglycerides level was estimated according to GPO-PAP enzymatic colorimetric method (Stein, 1987), (Spectrum Kit). The activities of serum ALT and AST were estimated calorimetrically according to the method of Reitman and Frankel (1957), (Spectrum kit). Serum urea level was determined according to urease colorimetric method (Tietz, 1990), (Spectrum Kit). Serum uric acid level was estimated according to uricase-POP enzymatic colorimetric method with 4-amino-antipyrine (Tietz, 1990), (Spectrum Kit). Serum creatinine level was estimated according to a colorimetric method described by Henry (1974).

\section{Histopathological studies:}

Immediately after dissection of the studied fish, parts of kidney, liver and spleen were carefully removed and fixed in $10 \%$ formalin at $4{ }^{\circ} \mathrm{C}$, for 48 hours then the samples were dehydrated in ascending grades of alcohol and cleared in xylene. The fixed tissues were embedded in paraffin wax and sectioned into five micrometers thick using Euromex Holland Microtome, and then stained according to Harris Hematoxylin and Eosin method. Finally, the sections were examined microscopically and photographed by a microscopic camera according the methods cited by Tayel et al. (2018).

\section{RESULTS AND DISCUSSION}

\section{Acute Toxicity (Determination of $96 \mathrm{hrs}-\mathrm{LC}_{50}$ of ammonia):}

The $96 \mathrm{hrs}-\mathrm{LC}_{50}$ of ammonia for Oreochromis niloticus fish have been calculated.

Tables (1\&2) demonstrated the mortality of Oreochromis niloticus at different concentrations of ammonia. The results showed that the $96 \mathrm{hrs}-\mathrm{LC}_{50}$ of ammonia was $38.4 \mathrm{mg} / \mathrm{l}$.

Table 1: Preliminary trials for zero and hundred \% mortalities in Oreochromis niloticus exposed to different concentrations of Ammonia (after $96 \mathrm{hrs}$ ).

\begin{tabular}{cccccccc}
\hline \multirow{2}{*}{ number } & $\begin{array}{c}\text { Concentrations of } \\
\text { ammonia (mg/l) }\end{array}$ & $\begin{array}{c}\text { Mortality number during } 96 \text { hrs } \\
1^{\text {st }} \text { day }\end{array}$ & $2^{\text {nd }}$ day & $3^{\text {rd }}$ day & $4^{\text {th }}$ day & $\begin{array}{c}\text { Total } \\
\text { mortality } \\
\text { Number }\end{array}$ & $\begin{array}{c}\text { Total } \\
\text { mortality } \\
\%\end{array}$ \\
\hline 1 & Control & 0 & 0 & 0 & 0 & 0 & 0 \\
2 & 20 & 0 & 0 & 0 & 0 & 0 & 0 \\
3 & 30 & 0 & 0 & 0 & 0 & 0 & \\
4 & 32 & 0 & 0 & 0 & 1 & 1 & 10 \\
5 & 34 & 0 & 0 & 1 & 2 & 3 & 30 \\
6 & 36 & 0 & 1 & 2 & 2 & 5 & 50 \\
7 & 38 & 0 & 1 & 1 & 3 & 5 & 50 \\
8 & 40 & 0 & 1 & 2 & 3 & 6 & 60 \\
9 & 42 & 0 & 2 & 2 & 3 & 7 & 70 \\
10 & 44 & 0 & 2 & 3 & 3 & 8 & 80 \\
11 & 46 & 0 & 2 & 2 & 4 & 8 & 80 \\
12 & 48 & 0 & 3 & 4 & 3 & 10 & 100 \\
\hline
\end{tabular}


Table 2: Actual estimation of $96 \mathrm{hrs}-\mathrm{LC}_{50}$ of ammonia for Oreochromis niloticus.

\begin{tabular}{cccccc}
\hline Number (N) & Concentrations mg/l & No. of dead fish at 96 hrs & A & b & Axb \\
\hline 2 & 20 & 0 & 0 & 0 & 0 \\
3 & 30 & 0 & 10 & 0 & 0 \\
4 & 32 & 1 & 2 & 0.5 & 1 \\
5 & 34 & 3 & 2 & 2 & 4 \\
6 & 36 & 5 & 2 & 4 & 8 \\
7 & 38 & 5 & 2 & 5 & 10 \\
8 & 40 & 6 & 2 & 5.5 & 11 \\
9 & 42 & 7 & 2 & 6.5 & 13 \\
10 & 44 & 8 & 2 & 7.5 & 15 \\
11 & 46 & 8 & 2 & 8 & 16 \\
12 & 48 & 10 & 2 & 9 & 18 \\
& & & & & \\
\hline
\end{tabular}

96 hrs- $\mathrm{LC}_{50}=$ Highest dose $-\Sigma \mathrm{axb} / \mathrm{n}$

$\mathrm{a}=$ constant factor between two successive doses.

$b=$ the mean of dead fish in each group.

$\Sigma \mathrm{axb}=$ sum of axb.

$\mathrm{N}=$ Number of fish in each groups

$=48-96 / 10$

$=38.4 \mathrm{mg} / \mathrm{l}$

In the present study ammonia decreased from $9.6 \mathrm{mg} / 1\left(0.25 \mathrm{LC}_{50}\right)$ and 19.2 $\mathrm{mg} / \mathrm{l}\left(0.50 \mathrm{LC}_{50}\right)$ at the first experiment to 0.7 and $4.1 \mathrm{mg} / \mathrm{l}$ at the end of the biofloc experiment, this means that the biofloc system removed about $92.7 \%$ and $78.7 \%$ of ammonia, respectively. As a consequence, nitrite concentration decreased and nitrate concentration increased. Thus, toxic ammonia has been converted into non-toxic nitrate through ammonia oxidation to nitrite then to nitrate by biological factors in the biofloc system such as phytoplankton (Fig. 1). The results of this study revealed that the application of BFT system improved water quality by controlling ammonia level and increasing of phytoplankton. The mode of action of BFT system is claimed to be enhancement of organic matter degradation, nitrification and ammonia removal. Nitrifying bacteria in a pond will always respond to the availability of substrate.

Thus, if a pond has high ammonia levels, nitrifying bacteria will respond by multiplying rapidly and their abundance will decline when ammonia concentration decrease. Phytoplankton in the biofloc system improves water quality and production performance of fish culturing by enhancing nitrification and ammonia removal. This observation agrees with Shalaby (2011); Rapatsa and Moyo (2013) and Sanchez et al. (2018).

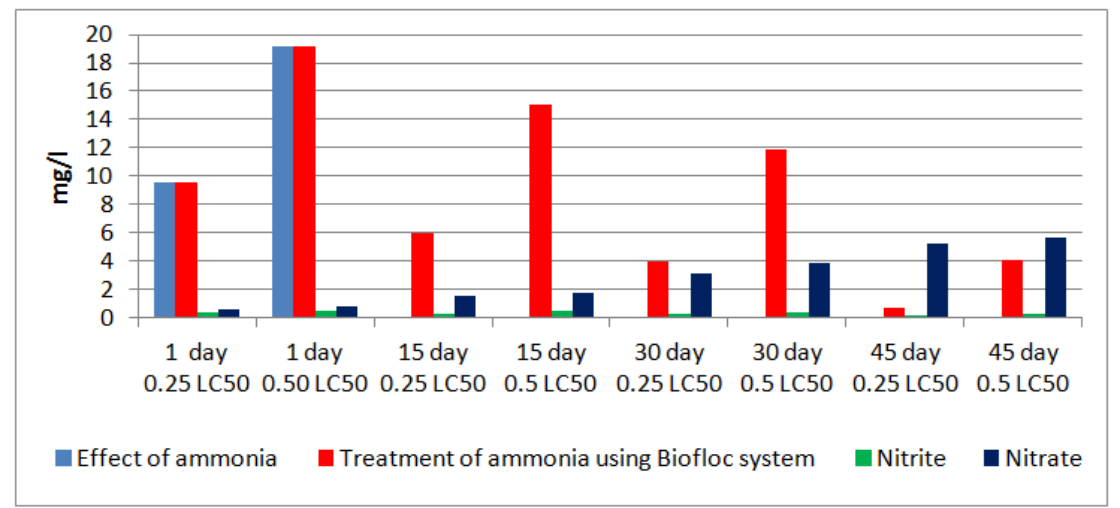

Fig. 1: Concentration of ammonia, nitrite, nitrate under effect of ammonia and biofloc system 


\section{Phytoplankton community structure:}

Microscopic examination of phytoplankton in experienced BFT system, along the investigated period, revealed that 29 species were identified, and its taxonomical classification was belonging to 4 classes, related to Chlorophyceae, $15 \mathrm{sp}$., Bacillariophyceae, 6 sp., Cyanophyceae, 5 sp. and Euglenophyceae, 3 sp. (Table 3).

Table 3: Identified phytoplankton in the studied biofloc system

\begin{tabular}{|c|c|}
\hline Groups & Species \\
\hline \multirow{15}{*}{ Chlorophyceae } & Actinastrum hantzschii \\
\hline & Ankistrodesmus fractus \\
\hline & Chlamydomonas angulosa \\
\hline & Chlorella vulgaris \\
\hline & Coelastrum microporum \\
\hline & Elakatothrix gelatinosa \\
\hline & Kirchneriella aperta \\
\hline & Kirchneriella obese \\
\hline & Monactinus simplex \\
\hline & Mucidosphaerium pulchellum \\
\hline & Nephrocytium limneticum \\
\hline & Oocystis pyriformis \\
\hline & Scenedesmus quadricauda \\
\hline & Tetraëdron minimum \\
\hline & Tetraëdron trigonum \\
\hline \multirow{6}{*}{ Bacillariophyceae } & Aulacoseira granulate \\
\hline & Ceratoneis closterium \\
\hline & Cyclotella meneghiniana \\
\hline & Fragilaria capucina var. vaucheriae \\
\hline & Lyrella lyra \\
\hline & Nitzschia acicularis \\
\hline \multirow{5}{*}{ Cyanophyceae } & Arthrospira jenneri \\
\hline & Chroococcus minor \\
\hline & Coelosphaerium dubium \\
\hline & Gloeocapsa punctuate \\
\hline & Phormidium inundatum \\
\hline \multirow{3}{*}{ Euglenophyceae } & Lepocinclis acus \\
\hline & Phacus chloroplasts \\
\hline & Trachelomonas hispida \\
\hline
\end{tabular}

Average of the class composition ratio cleared that Chlorophyceae was the most predominated, forming about $69 \%$ and $88 \%$ in $0.50 \mathrm{LC}_{50}$ and $0.25 \mathrm{LC}_{50}$ ammonia, respectively from the total phytoplankton density, followed by Bacillariophyceae, representing about $22.1 \%$ in $0.50 \mathrm{LC}_{50}$. While in $0.25 \mathrm{LC}_{50}$ revealed Euglenophyceae in the second order which recorded 4.7\% (Fig. 3). Zita and Hermansson (1994) and Arifin et al. (2018) showed Chlorophyceae and Bacillariophyceae are the dominant phytoplankton classes in BFT treatments. Schrader et al. (2011) mentions that phytoplanktonic composition in an outdoor freshwater pond of catfish, was dominated by green algae, diatoms and cyanobacteria. The population density of phytoplankton in experienced BFT system had examined first day, after 30 days and after 45 days. The highest phytoplankton density of $226 \times 10^{5}$ unit/l and $258 \times 10^{5}$ unit/l in $0.50 \mathrm{LC}_{50}$ and $0.25 \mathrm{LC}_{50}$, respectively was occurred after 45 days, and the least count was $74 \times 10^{5}$ unit/l and $73 \times 10^{5}$ unit/1 in $0.50 \mathrm{LC}_{50}$ and $0.25 \mathrm{LC}_{50}$, respectively that was recorded in the first day (Fig. 2). 


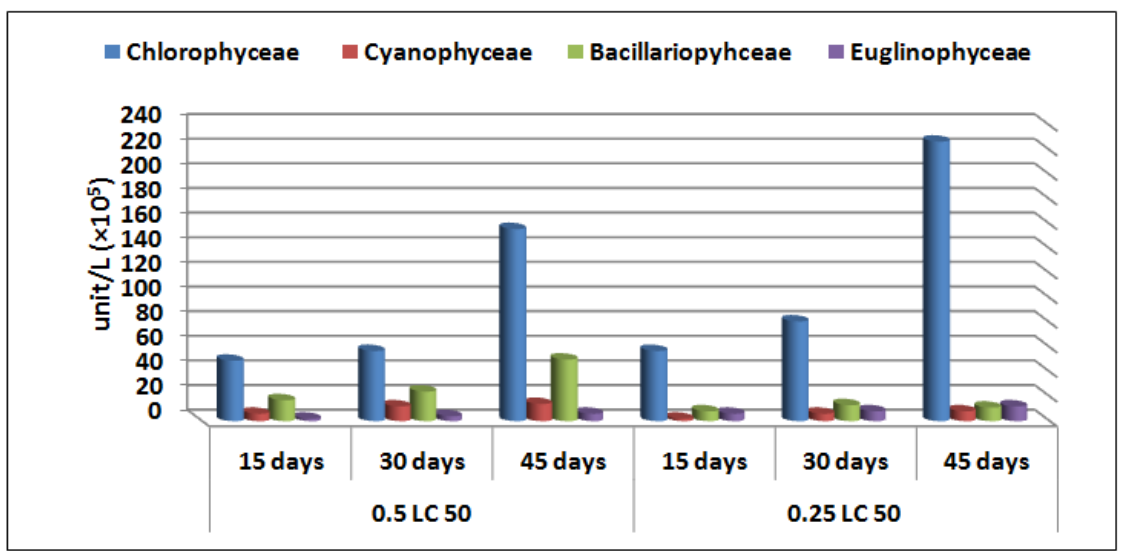

Fig. 2: Phytoplankton density in the biofloc system with two concentrations of ammonia.

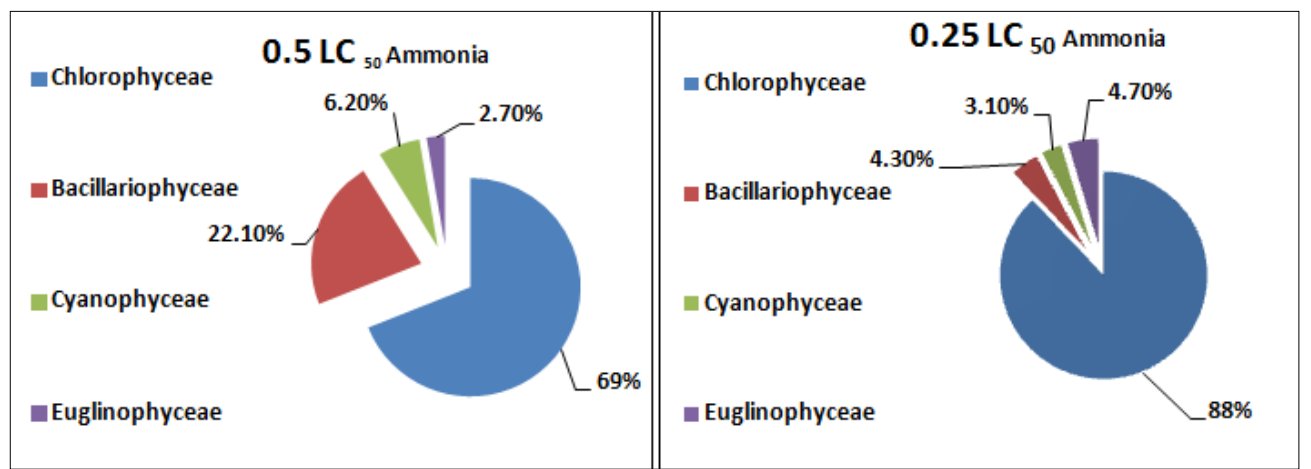

Fig. 3: phytoplankton class composition ratio in the studied BFT system Canonical Correlation Analysis

Distribution and abundance of the most common species of phytoplankton

Systematic classification of Phytoplankton in BFT system during the investigated period revealed that members of phytoplankton (29 sp.) were manly dominated with Arthrospira jenneri, Chlorella vulgaris, Chroococcus minor, Coelosphaerium dubium, Gloeocapsa punctata, Phacus chloroplasts, Phormidium inundatum and Scenedesmus quadricauda (Table 4).

Table 4: Densities and abundances of the most leading species of phytoplankton in the studied BFT system

\begin{tabular}{|c|c|c|c|c|c|c|}
\hline \multirow{3}{*}{ Dominant species } & \multicolumn{6}{|c|}{ Count (No. of units $\left.\times 10^{5} / \mathrm{l}\right)$} \\
\hline & \multicolumn{3}{|c|}{$0.5 \mathrm{LC}_{50}$} & \multicolumn{3}{|c|}{$0.25 \mathrm{LC}_{50}$} \\
\hline & 15 day & 30 day & 45day & 15 day & 30 day & 45 day \\
\hline Arthrospira jenneri & 2 & 2 & 10 & 2 & 4 & 0 \\
\hline Chlorella vulgaris & 31 & 37 & 89 & 35 & 56 & 180 \\
\hline Chroococcus minor & 4 & 7 & 2 & 2 & 2 & 2 \\
\hline Coelosphaerium dubium & 5 & 2 & 13 & 0 & 0 & 2 \\
\hline Gloeocapsa punctata & 4 & 4 & 8 & 2 & 2 & 0 \\
\hline Phacus chloroplastes & 2 & 4 & 4 & 0 & 0 & 10 \\
\hline Phormidium inundatum & 2 & 9 & 17 & 2 & 5 & 7 \\
\hline Scenedesmus quadricauda & 10 & 12 & 16 & 14 & 21 & 23 \\
\hline
\end{tabular}

Chlorella vulgaris was the most common species of phytoplankton in BFT system which revealed in the final of experiment $39.4 \%$ and $69.8 \%$ in $0.50 \mathrm{LC}_{50}$ and $0.25 \mathrm{LC}_{50}$ treatments, respectively, followed with Phormidium inundatum and Scenedesmus quadricauda in $0.50 \mathrm{LC}_{50}$ ( $7.5 \%$ and $7.1 \%$, respectively), while in 0.25 $\mathrm{LC}_{50}$, represented Scenedesmus quadricauda and Phacus chloroplasts as second and third predominant species of phytoplankton (8.9\% and 3.9\%, respectively). 
These results were in agreement with the results of Shawky et al. (2015) who revealed that green microalga Scenedesmus quadricauda reaching a maximum removal percentage of $1 \mathrm{mg} / \mathrm{l}$ ammonia to about $100 \%$ after 4 days; while, at $5 \mathrm{mg} / \mathrm{l}$ ammonia concentrations, the maximum removal percentage reached $91.8 \%$ after 4 days.

Su et al. (2012) revealed that removal efficiency of total nitrogen $(26.5 \mathrm{mg} / \mathrm{l})$ reached 100\% using Phormidium sp. and Chlamydomonas Reinhardtii after 4 days, respectively. Kim et al. (2010, 2013); Choi and Lee (2013) and Zhu et al. (2013) studied the removal efficiency of Chlorella sp. using different concentrations of ammonia and they revealed that it was able to remove from 64 to $100 \%$ ammonia after few days.

Canonical Correspondence Analysis (CCA) is carried out for analyzing 3 environmental variables $\left(\mathrm{NO}_{2}, \mathrm{NO}_{3}\right.$ and $\left.\mathrm{NH}_{4}\right)$ and 8 dominant phytoplankton species (mentioned in table 4) in each of $0.50 \mathrm{LC}_{50}$ and $0.25 \mathrm{LC}_{50}$, as in Figs. 4 and 5.

Most phytoplankton species showed centroid distribution revealing accumulative affect of different environmental variables such Chlorella vulgaris, Scenedesmus quadricauda and Gloeocapsa punctatain Figure 4, and Chlorella vulgaris, Scenedesmus quadricauda, Chroococcus minor and Phormidium inundatum and other species around the center in Figure 5.

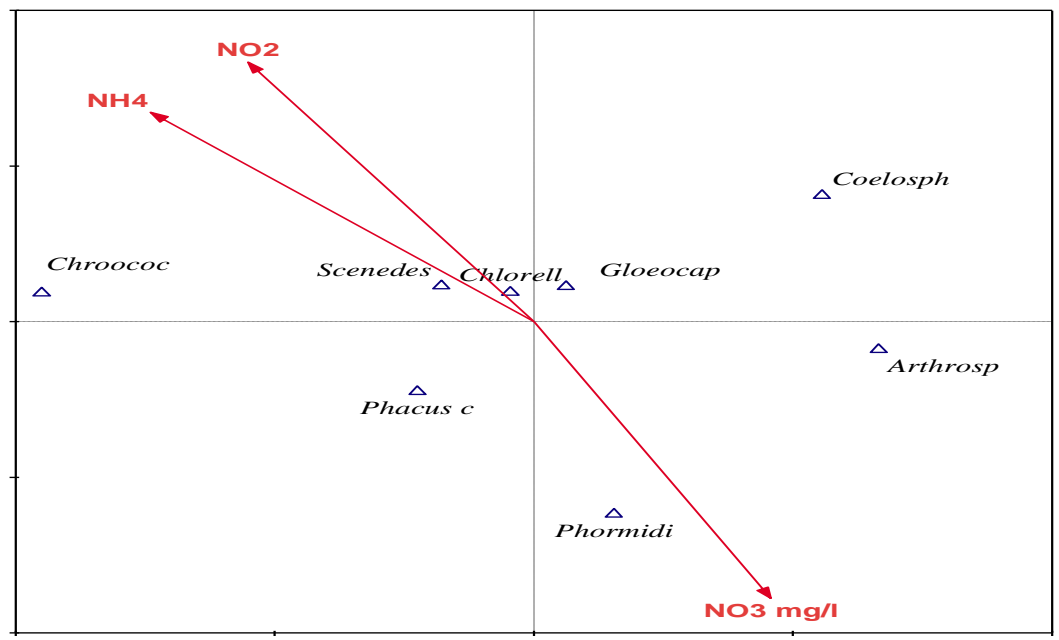

Fig. 4: CCA of phytoplankton species with the environmental parameters at BFT system at $0.50 \mathrm{LC}_{50}$ ammonia concentration .

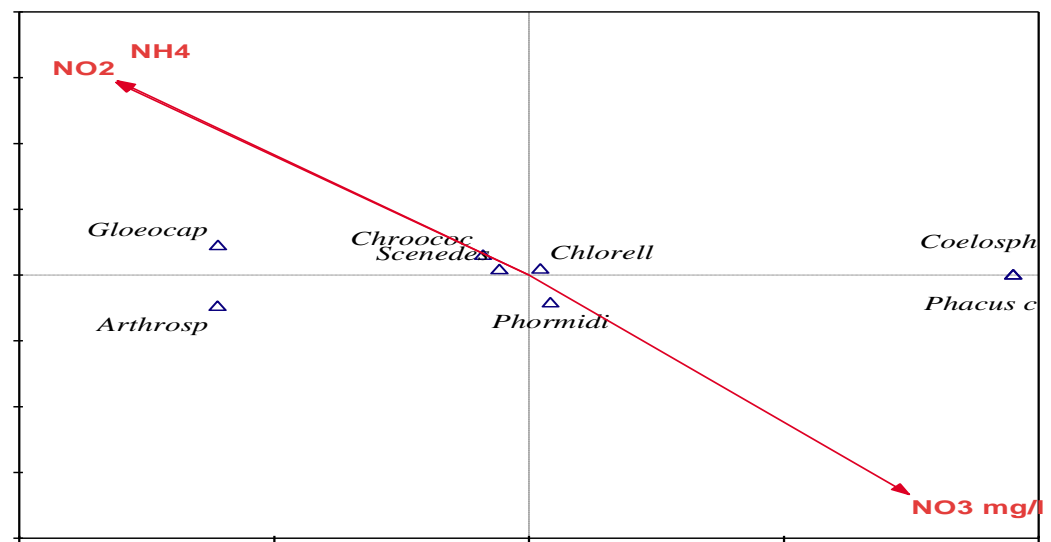

Fig. 5: CCA of phytoplankton species with the environmental parameters at BFT system at $0.25 \mathrm{LC}_{50}$ ammonia concentration 


\section{Effect of ammonia and biofloc system on the hematology and histology of Oreochromis niloticus fish: \\ Hematology:}

The results of serum glucose, protein, albumin, cholesterol, triglycerides, ALT and AST, urea, uric acid and createnine levels, obtained from experimental fish illustrated in figures (6-15).

The obtained glucose values increased from $125 \mathrm{mg} / \mathrm{dI}$ at first experiment affected by $0.25 \mathrm{LC}_{50}$ ammonia to $293 \mathrm{mg} / \mathrm{dI}$ at end of experiment affected by 0.50 $\mathrm{LC}_{50}$ Ammonia, while the values decreased from 120 to 98 and from 130 to $110 \mathrm{mg} / \mathrm{dl}$ affected by $0.25 \mathrm{LC}_{50}$ and $0.50 \mathrm{LC}_{50}$ ammonia and biofloc. In control group glucose value was $88 \mathrm{mg} / \mathrm{dI}$ (Fig.6). Total protein values ranged from 3.7 to $4.6 \mathrm{~g} / \mathrm{dI}$ at the beginning of the experiment to 5.2 and $6.3 \mathrm{~g} / \mathrm{dI}$ at end of experiment affected by 0.25 $\mathrm{LC}_{50}$ and $0.50 \mathrm{LC}_{50}$ ammonia, while value decreased from 3.9 to 3.6 and from 4.3 to $3.8 \mathrm{~g} / \mathrm{dl}$ in fish affected by $0.25 \mathrm{LC}_{50}$ and $0.50 \mathrm{LC}_{50}$ ammonia and biofloc. In control group, protein level was $3.5 \mathrm{~g} / \mathrm{dl}$ (Fig. 7). Albumin values decreased from $1.8 \mathrm{~g} / \mathrm{dI}$ at to $1.1 \mathrm{~g} / \mathrm{dI}$ in fish affected by $0.25 \mathrm{LC}_{50}$ and $0.50 \mathrm{LC}_{50}$ (ammonia), while value increased from 1.6 to $1.8 \mathrm{~g} / \mathrm{dl}$ in fish affected by $0.50 \mathrm{LC}_{50}$ ammonia and biofloc. In control group, albumin value was $1.9 \mathrm{~g} / \mathrm{dl}$ (Fig. 8). Cholesterol values increased from $81 \mathrm{mg} / \mathrm{dI}$ to $189 \mathrm{mg} / \mathrm{dI}$ at in fish affected by $0.25 \mathrm{LC}_{50}$ and $0.50 \mathrm{LC}_{50}$ ammonia, while the value ranged from 85 to $101 \mathrm{~g} / \mathrm{dI}$ affected by $0.25 \mathrm{LC}_{50}$ and $0.50 \mathrm{LC}_{50}$ ammonia and biofloc respectively. In control group cholesterol value was $78 \mathrm{mg} / \mathrm{dl}$ (Fig. 9). Triglycerides values ranged from 120 and $135 \mathrm{mg} / \mathrm{dI}$ to 187 and $258 \mathrm{mg} / \mathrm{dl}$ in fish affected by $0.25 \mathrm{LC}_{50}$ and $0.50 \mathrm{LC}_{50}$ ammonia, while values decreased from 117 and 130 to 104 and $115 \mathrm{mg} / \mathrm{dl}$ in fish affected by $0.25 \mathrm{LC}_{50}$ and $0.50 \mathrm{LC}_{50}$ ammonia and biofloc. In control group, triglycerides value was $100 \mathrm{mg} / \mathrm{dl}$ (Fig. 10). AST values ranged from 58.6 to $116 \mathrm{IU} / \mathrm{ml}$ at the beginning of the experiment to 183 and 275 $\mathrm{IU} / \mathrm{ml}$ at end of experiment in fish affected by $0.25 \mathrm{LC}_{50}$ and $0.50 \mathrm{LC}_{50}$ ammonia, while AST values decreased from 55.6 and $113 \mathrm{IU} / \mathrm{ml}$ to 40 and $28.7 \mathrm{IU} / \mathrm{ml}$ at the end experimental in fish affected by $0.25 \mathrm{LC}_{50}$ and $0.50 \mathrm{LC}_{50}$ ammonia and biofloc. In control group, AST value was $35 \mathrm{IU} / \mathrm{ml}$ (Fig. 11). ALT values elevated from 29.3 $\mathrm{IU} / \mathrm{ml}$ at the beginning of the experiment affected by $0.25 \mathrm{LC}_{50}$ ammonia to $68 \mathrm{IU} / \mathrm{ml}$ at end of experiment affected by $0.50 \mathrm{LC}_{50}$ ammonia, while in fish affected by ammonia and biofloc, ALT values ranged from 24.2 to $33.3 \mathrm{IU} / \mathrm{ml}$. In control group ALT value was $20 \mathrm{IU} / \mathrm{ml}$ (fig. 12). Urea values increased from $38 \mathrm{mg} / \mathrm{dI}$ at the beginning of the experiment affected by $0.25 \mathrm{LC}_{50}$ ammonia to $85 \mathrm{mg} / \mathrm{dI}$ at end of experiment affected by $0.50 \mathrm{LC}_{50}$ ammonia, while values ranged from 38 to 26.5 $\mathrm{mg} / \mathrm{dl}$ in fish affected by ammonia and biofloc. In control group urea value was 25.0 $\mathrm{mg} / \mathrm{dl}$ (Fig. 13). Uric acid values ranged from $4.8 \mathrm{mg} / \mathrm{dI}$ at the beginning of the experiment affected by $0.25 \mathrm{LC}_{50}$ ammonia to $14.5 \mathrm{mg} / \mathrm{dI}$ at end of experiment affected by $0.50 \mathrm{LC}_{50}$ (ammonia), while the values ranged from 4.2 to $5.3 \mathrm{mg} / \mathrm{dI}$ in fish affected by ammonia and biofloc. In control group uric acid value was $4 \mathrm{mg} / \mathrm{dl}$ (Fig. 14). Creatinine values decreased from $0.55 \mathrm{mg} / \mathrm{dI}$ at the beginning of the experiment affected by $0.25 \mathrm{LC}_{50}$ ammonia to $0.25 \mathrm{mg} / \mathrm{dI}$ at end of experiment affected by $0.50 \mathrm{LC}_{50}$ (ammonia), while values ranged from 0.50 to $0.65 \mathrm{mg} / \mathrm{dI}$ in fish affected by ammonia and biofloc. In control group creatinine value was $0.70 \mathrm{mg} / \mathrm{dl}$ (Fig. 15). Nowadays cultured Nile Tilapia suffering from several problems such as excess ammonia which is toxic to fish leads to several hematological and histological alterations in cultured fish.

Hematology is important in monitoring physiological and pathological changes in fish. Blood parameters vary in different fish species and this reflects 
adaptation to the varied environment conditions (Adeyemo, 2007). A change in the mentioned hematological parameters in present syudy indicates worsening of the organism's health status.It has been claimed by the proponents of BFT system that it enhances the fish immune system. Fish in organically manured ponds are pron to infections by several pathogens. Application of BFT was supposed to boost the fish immunity. In this study, what measured parameters which verified this statement, this noticfication also recorded by Ali et al. (2011) and Hanna et al. (2014).

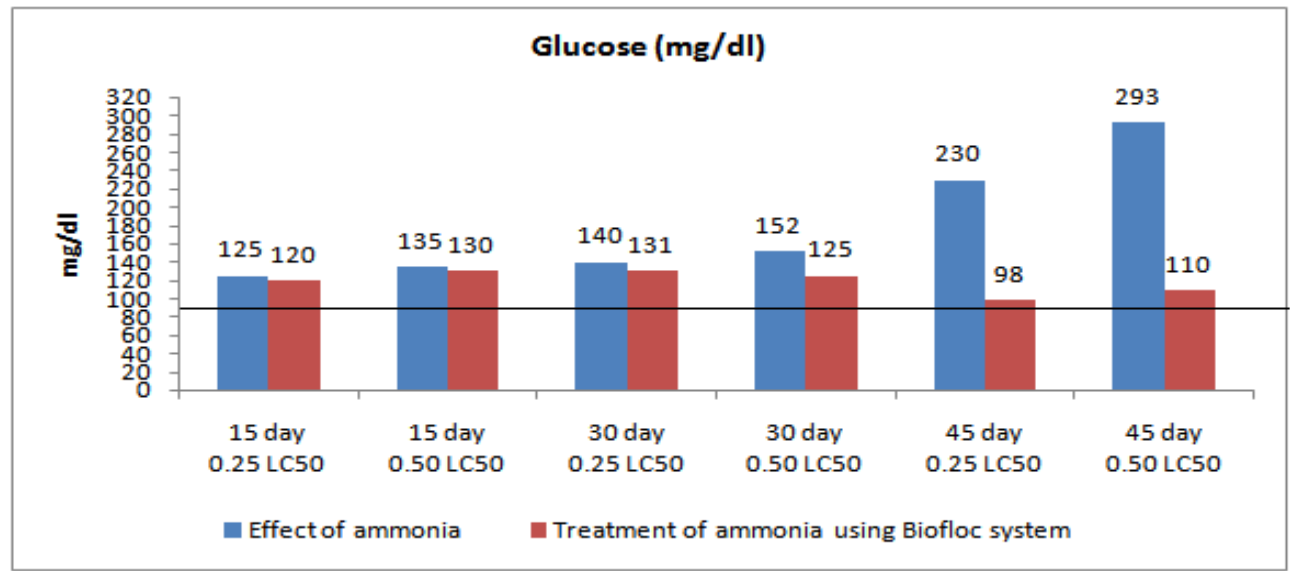

Fig. 6: Effect of ammonia and biofloc system ( 0.25 and $0.50 \mathrm{LC}_{50}$ of ammonia) on glucose $\mathrm{f}$ Oreochromis niloticus, (- Black line) control.

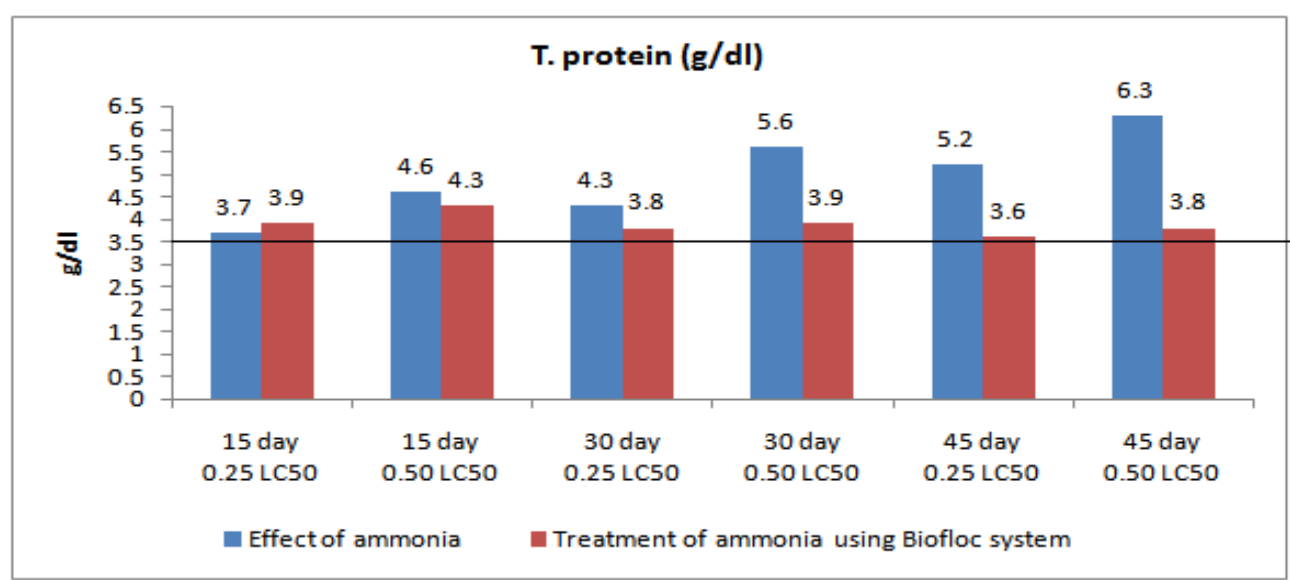

Fig. 7. Effect of ammonia and biofloc system $\left(0.25\right.$ and $0.50 \mathrm{LC}_{50}$ of ammonia) on total protein levels of Oreochromis niloticus, (— Black line) control.

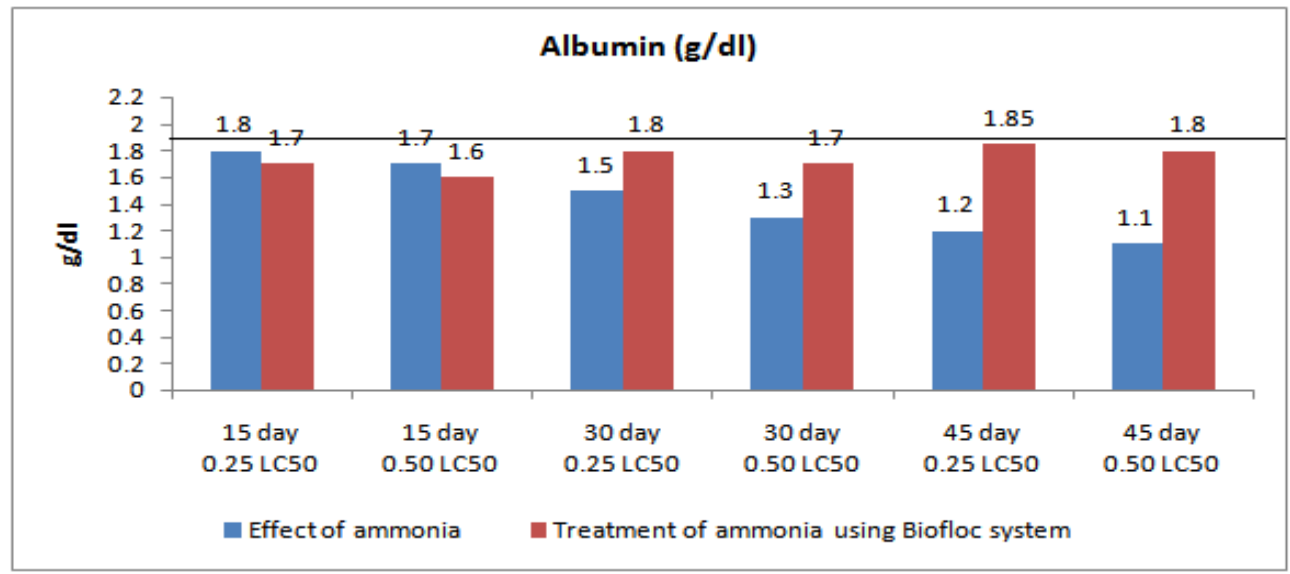

Fig. 8. Effect of ammonia and biofloc system ( 0.25 and $0.50 \mathrm{LC}_{50}$ of ammonia) on albumin levels of Oreochromis niloticus, (— Black line) control. 


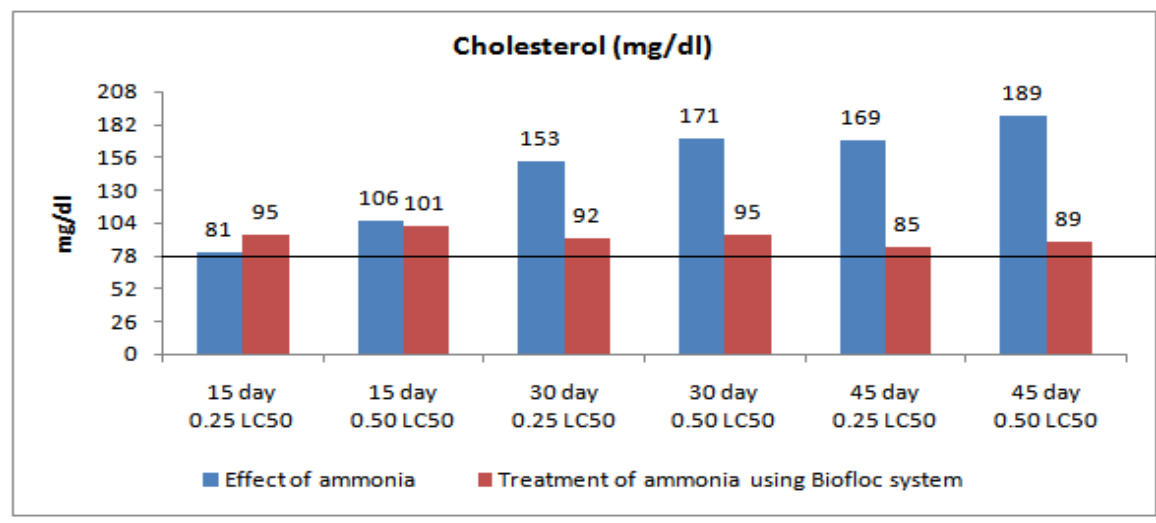

Fig. 9. Effect of ammonia and biofloc system $\left(0.25\right.$ and $0.50 \mathrm{LC}_{50}$ of ammonia) on cholesterol levels of Oreochromis niloticus, (— Black line) control.

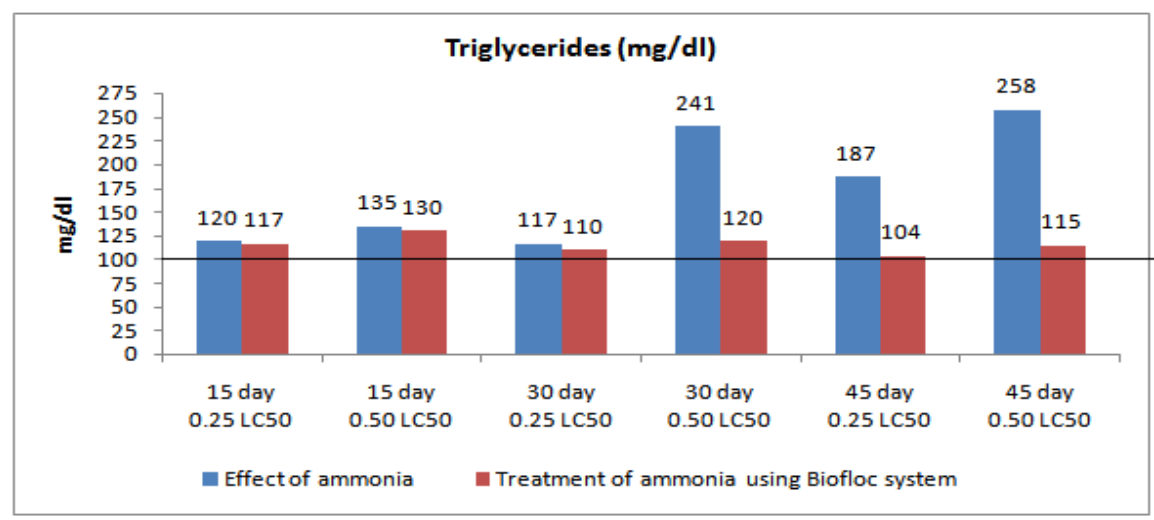

Fig. 10. Effect of ammonia and biofloc system $\left(0.25\right.$ and $0.50 \mathrm{LC}_{50}$ of ammonia on triglycerides levels of Oreochromis niloticus, (— Black line) control.

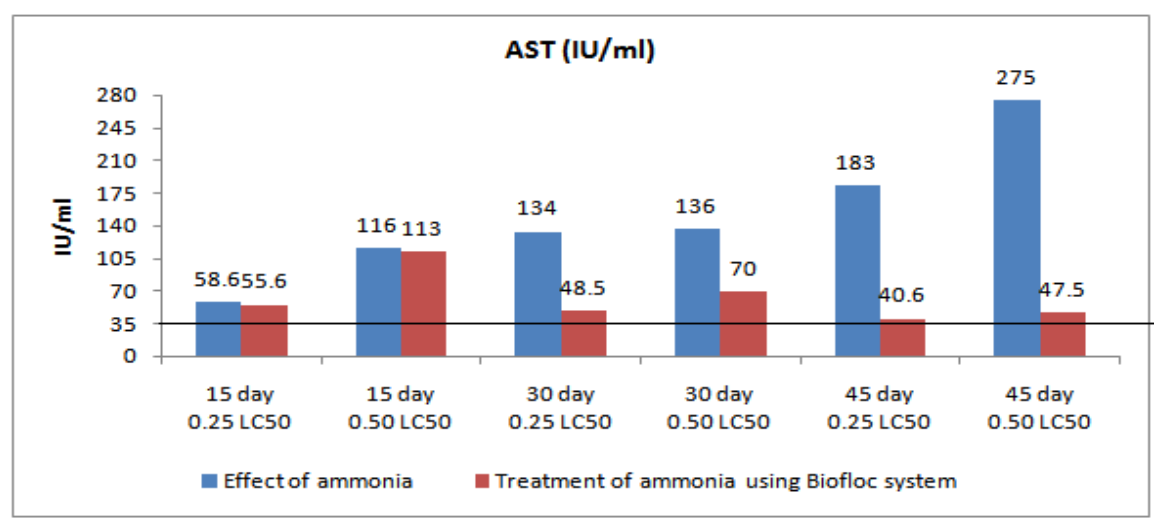

Fig. 11. Effect of ammonia and biofloc system (0.25 and $0.50 \mathrm{LC}_{50}$ of ammonia) on AST activities of Oreochromis niloticus, (_ Black line) control.

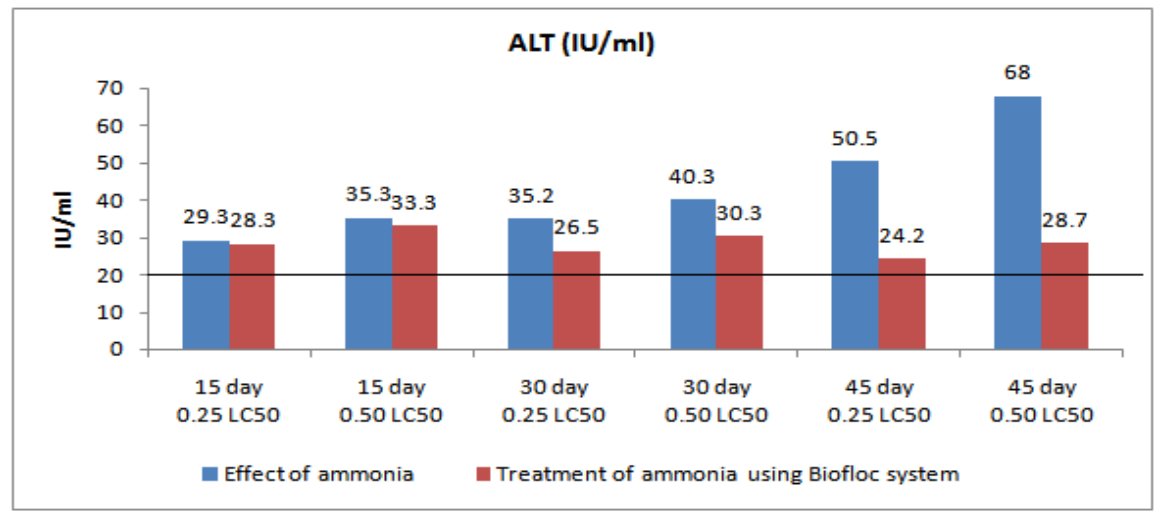

Fig. 12. Effect of ammonia and biofloc system (0.25 and $0.50 \mathrm{LC}_{50}$ of ammonia) on ALT activities of Oreochromis niloticus, (— Black line) control. 


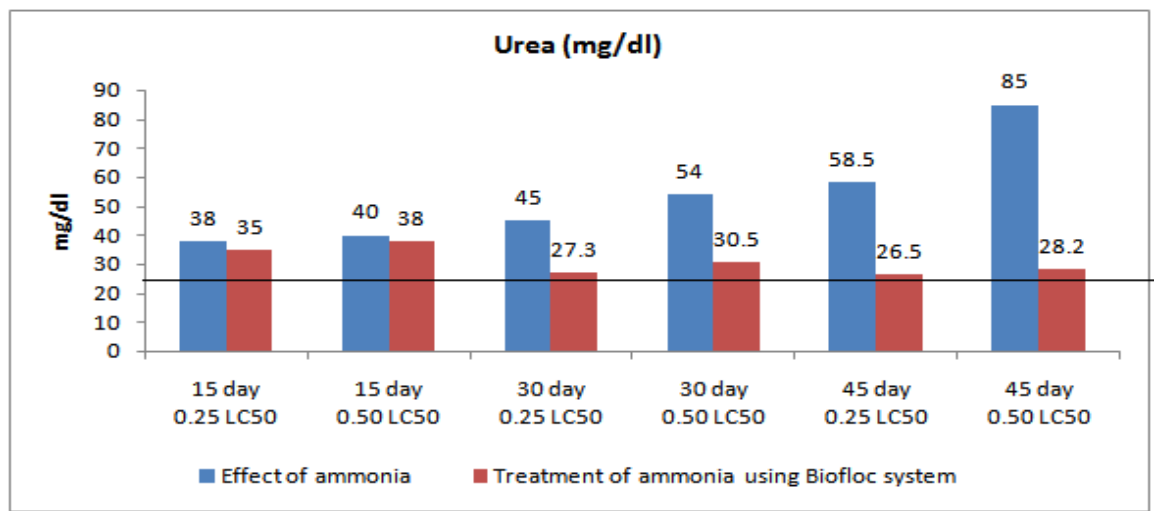

Fig. 13. Effect of ammonia and biofloc system (0.25 and $0.50 \mathrm{LC}_{50}$ of ammonia) on urea levels Oreochromis niloticus, (_ Black line) control.

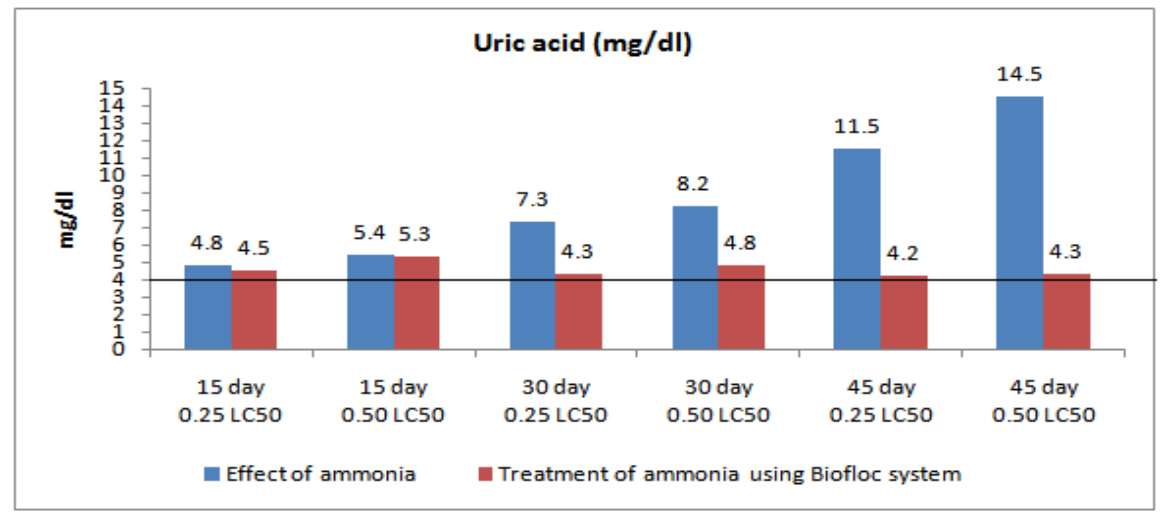

Fig. 14. Effect of ammonia and biofloc system (0.25 and $0.50 \mathrm{LC}_{50}$ of ammonia) on uric acid levels of Oreochromis niloticus, (_ Black line) control.

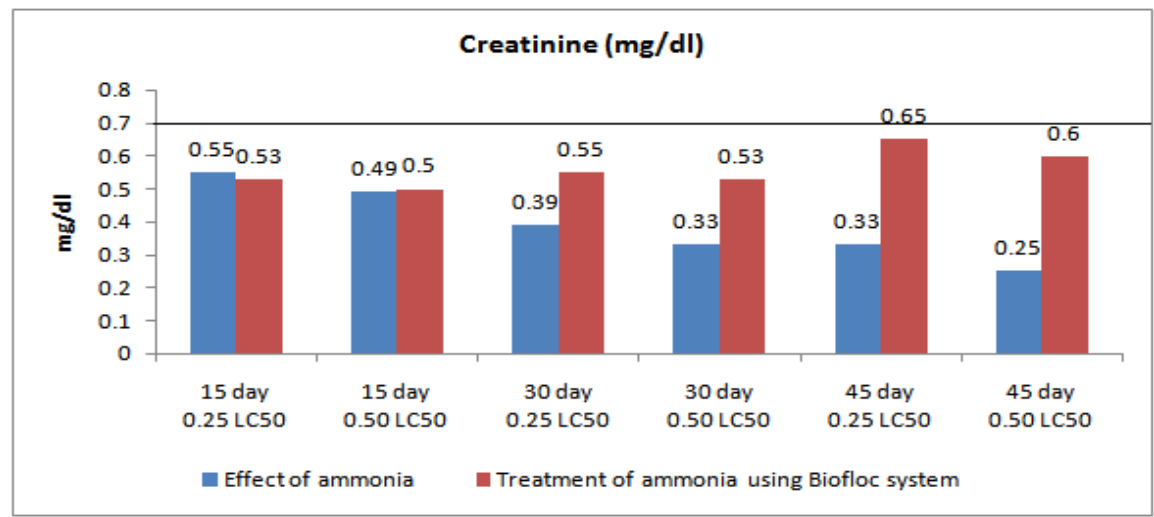

Fig. 15. Effect of ammonia and biofloc system (0.25 and $0.50 \mathrm{LC}_{50}$ of ammonia) on creatinine levels of Oreochromis niloticus, (_ Black line) control.

\section{Histology:}

Several histopathological alterations were observed in kidneys, liver and spleen of Oreochromis niloticus exposed to ammonia, while the control and treated groups appeared nearly normal.

As observed in Figure (16), Kidney tubules and Malpigian corpuscles in control (Fig. 16a) and treated (Figs. $16 \mathrm{d \& e}$ ) groups showed normal appearance, while the group affected by ammonia $\left(0.25 \mathrm{LC}_{50}\right.$ and $\left.0.50 \mathrm{LC}_{50}\right)$ (Figs. $16 \mathrm{b \& c}$ ) showed degeneration and sever degeneration and necrosis, respectivity. In figure (17), the liver section of control group fish showed Hepatic cells are near normal (Fig. 17a). In ammonia affected group $\left(0.25 \mathrm{LC}_{50}\right)$, the liver showed degeneration, necrosis and condesion in blood sinusoid (Fig. 17b), while the group affected by $0.50 \mathrm{LC}_{50}$ ammonia the liver suffer from severe fatty degeneration and piknosis (Fig. 17c). Fish 
group treated by biofloc with $0.25 \mathrm{LC}_{50}$ ammonia, the liver showed improvement in hepatic cells with rare piknosis (Fig. 17d). However, fish that treated by $0.50 \mathrm{LC}_{50}$ and biofloc system cleared slightly improvement in liver cells with piknosis (Fig. $17 \mathrm{e})$.
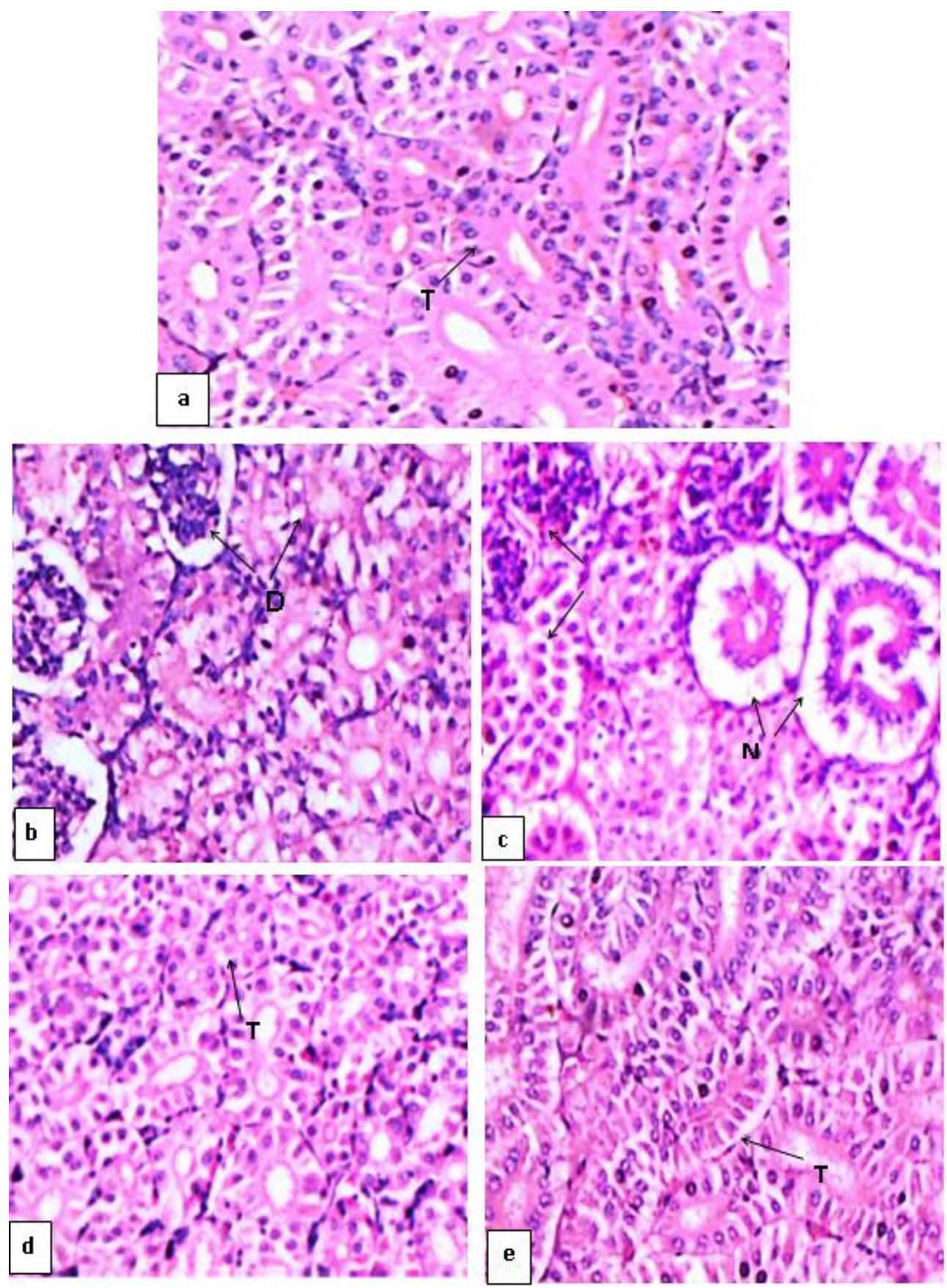

Fig. 16: Showing kidney section; (a): For controled fish showing: Kidney tubules (T) appear nearly as normal structure. (b): For fish affected by $0.25 \mathrm{LC}_{50}$ ammonia showing: Degeneration (D) in Kidney tubules and Malpigian curpacels. (c): For fish affected by $0.50 \mathrm{LC}_{50}$ ammonia showing: Severe degeneration (D) and necrosis (N) in Kidney tubules and Malpigian curpacels. (d): For fish treated by $0.25 \mathrm{LC}_{50}$ Biofloc system showing improvement in Kidney tubules.(e): For fish treated by 0.50 Biofloc system showing slightly improvement in Kidney tubules. HandE. 

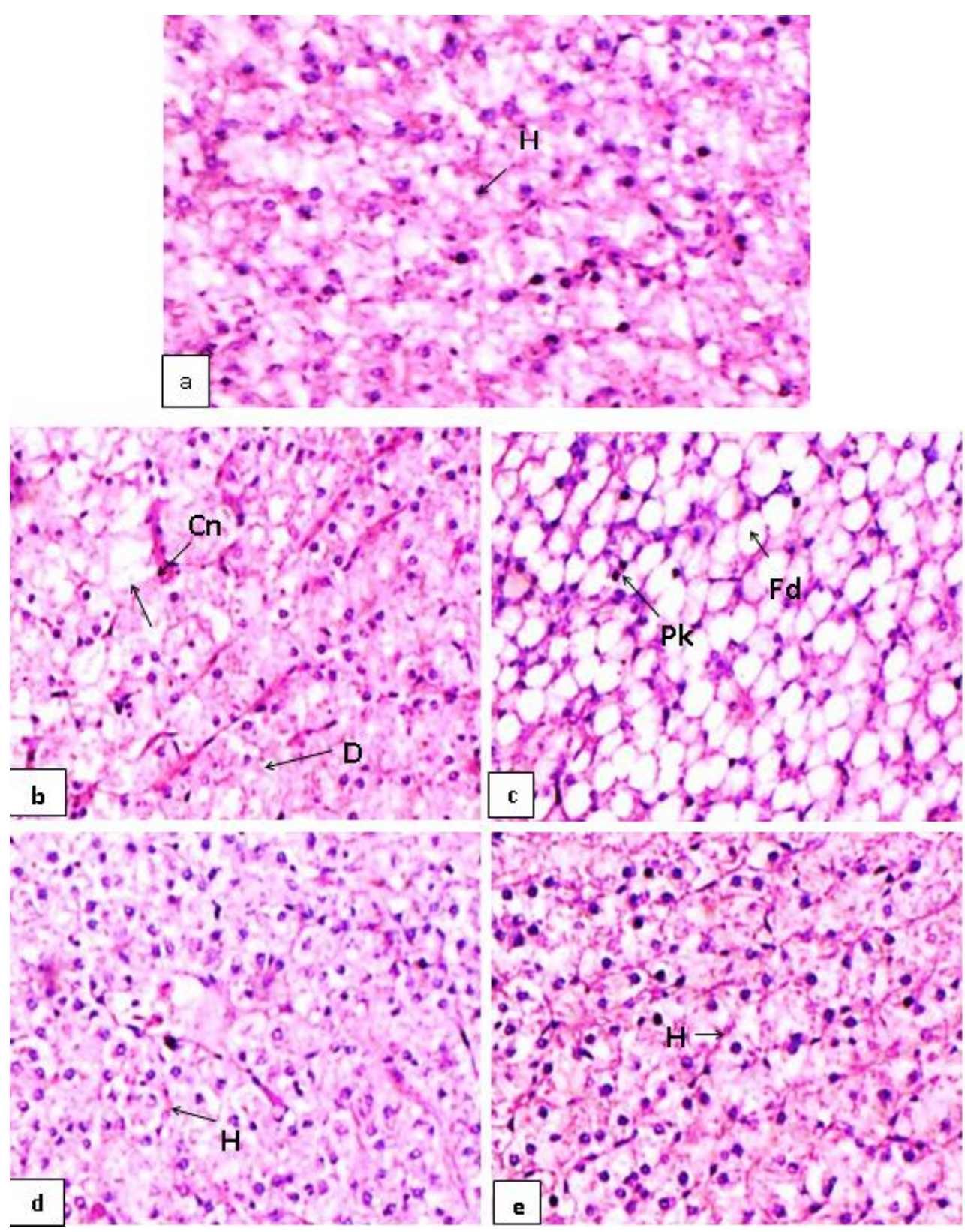

Fig. 17: Showing liver section; (a): For controled fish showing: Hepatic cells are near normal (H). (b): For fish affected by $0.25 \mathrm{LC}_{50}$ ammonia showing degeneration (D), necrosis $(\mathrm{N})$ and Congesion in blood sinusoid (Cn). (c): For fish affected by $0.50 \mathrm{LC}_{50}$ ammonia showing: Severe fatty degeneration (Fd) and Piknosis (Pk) in liver cell nucleus. (d): For fish treated by 0.25 Biofloc system showing improvement in liver cells $(\mathrm{H})$.(e): For fish treated by 0.50 Biofloc system showing slightly improvement in liver cells $(\mathrm{H})$. H\&E.

The spleenic tissue in control fish appeared relatively normal (Fig. 18a). There were necrosis, fibrosis, hemorrahge and hemosidrin in the spleen of fish exposed to $0.25 \mathrm{LC}_{50}$ ammonia Fig. 18, while the group affected by $0.50 \mathrm{LC}_{50}$ ammonia showed sever hemosidrin. While, slightly improvement was observed in most of fish treated group (Fig. $18 \mathrm{~d} \&$ e) as well as red and white bulp were become more improved in $0.25 \mathrm{LC}_{50}$ ammonia and biofloc system.

Kidney is a vital organ in the body and maintains the homeostasis in fish. It is not only involved in removal of wastes from blood but it is also responsible for selective re-absorption, which help in maintaining $\mathrm{pH}$, volume of blood, erythropoiesis and body fluids. Kidney is one of the first organs affected by 
contaminants in the water (Tayel et al., 2014 and bayomy et al., 2017).

Liver in fish is responsible of the storage glucose, digestion and filtration. Also, produce many enzymes that are stored in the gall bladder. These enzymes help in the breakdown of food. Generally, it is considered as the principal organ of absorption and detoxification in vertebrates and particularly in fish (Yacoub et al., 2008 and Tayel et al., 2018).

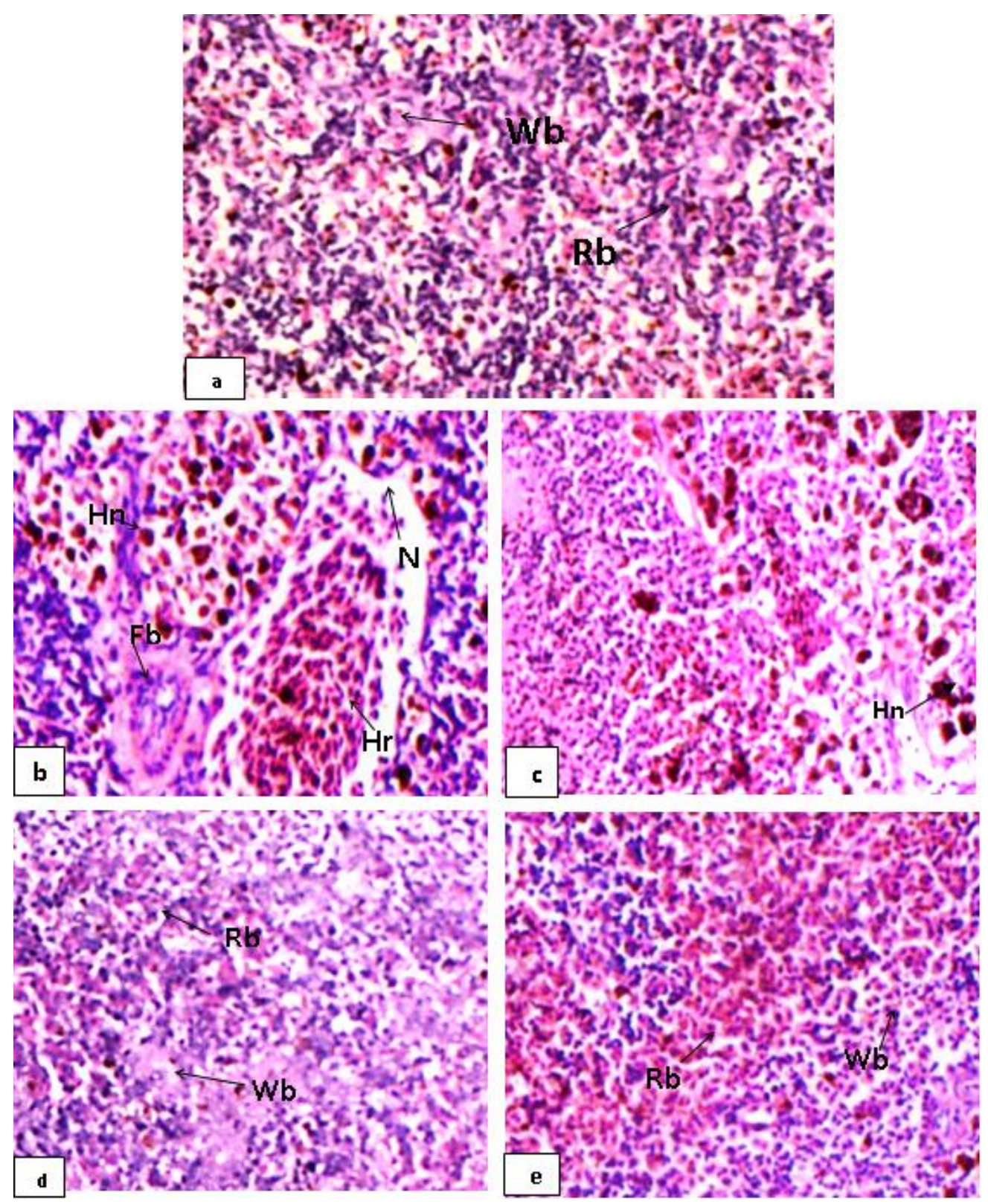

Fig. 18: Showing spleen section; (a): For controled fish showing: Normal in Red (RB) and White (WB) bulb. (b): For fish affected by $0.25 \mathrm{LC}_{50}$ ammonia showing: Necrosis (N), fibrosis ( $\left.\mathrm{Fb}\right)$ hemorrahge (Hr) and hemosidrin (Hn) in spleenic tissue. (c): For fish affected by $0.50 \mathrm{LC}_{50}$ ammonia showing: Severe hemosidrin (Hn) in spleenic tissue. (d): For fish treated by $0.25 \mathrm{LC}_{50}$ Biofloc system showing improvement in spleenic tissues (Red (RB) and White (WB) bulb). (e): For fish treated by 0.50 Biofloc system showing slightly improvement in spleenic tissues(Red (RB) and White (WB) bulb ). H\&E

The Spleen of fish is a hematopoietic tissue which forms the red blood cells and found as a small red mass. The spleen function is the filtration of blood, producing and storage of red blood cells, removing old and abnormal erythrocytes and producing 
antibody against blood born antigens (Saad et al., 2011).

The lesions that observed in kidney, liver and spleen of studed fish were degeneration, necrosis, piknosis, congesion hemorrhage, hemosidrin. Although these lesions were not fatal but every of them can be an indicator of a disorder in fish body or farm pond. In intense degeneration, it may lead to fatty degeneration, necrosis and piknosis. Also, hemorrhage and hemosidrin could represent by blood vessel disorders. These observations observation agree with that recorded by Younes et al. (2015) and Abu-Elala et al. (2016).

In conclusion, the present study indicates that the alterations that observed in the hematological parameters and histological structures in studied fish are mainly related to interactions between ammonia intoxication and biofloc introduced into fish ponds.

\section{REFERENCES}

Abu-Elala, N. M.; Abd-Elsalam, R. M.; Marouf. S.; Abdelaziz, M. and Moustafa, M. (2016). Eutrophication, Ammonia Intoxication, and Infectious Diseases: Interdisciplinary Factors of Mass Mortalities in Cultured Nile Tilapia. Journal of Aquatic Animal Health, 145:187-198.

Adeyemo, O. K. (2007). Hematological profile of Clarias gariepinus (Burchell, 1822) exposed to lead. Turk. J. Fish. Aquatic Sci., 7:163-169.

Ali, S. M.; Wafa, M. I. A. and Abbas, W. I. (2011). Evaluation of Azotobacter and Azospirillum biofertilizer as a probiotics in Oreochromis niloticus aquaculture J. Fish. Aquat. Sci., 6:535-544.

APHA (American Public Health Association) (2012). Standard Methods for the examination of water and wastewater. 22nd ed. Washington: $1360 \mathrm{pp}$. ISBN 978-087553-013-0.

Arifin, N. B.; Fakhri, M.; Yuniarti, A. and Hariati, A. M. (2018). Phytoplankton community at intensive cultivation system of whiteleg shrimp, Litopenaeus vannamei in Probolinggo, East Java. International Journal of Fisheries and Aquatic Studies, 6(2): 42-46.

Bayomy, M. F. F.; Elewa, A. A.; Tayel, S. I.; El-Kasheif, M. A. and El- Zeer M. E. (2017). Toxicological studies of water with a particular reference to its effect on Clarias gariepinus fish at El-Bahr El- Pharaony drain, El-Menoufiya Governorate, Egypt. Journal of Bioscience and Applied Research, 3 (3): 265272.

Behrens and Karper (1953). Determination of LC50. Arch. Furexp. Path. Undpharm, 28-177.

Bellinger, E. G. and Sigee, D. C. (2010). Fresh water algae: Identification and use as bioindicators. 1st edition by John Wiley and Sons, Ltd, $284 \mathrm{pp}$.

Brune, D. E.; Schwartz, G.; Eversole, A. G.; Collier, J. A. and Schwedler, T. E. (2003). Intensification of pond aquaculture and high rate photosynthetic systems. Aquac Eng, 28:65-86.

Case, M.; Leca, E. E.; Leitao, S. N.; Sant'Anna, E. E.; Schwamborn, R. and Junior, A. T. D. (2008). Plankton community as an indicator of water quality in tropical shrimp culture ponds. Marine Pollution Bulletin, 56:1343-1352.

Choi, H. J. and Lee, S. M. (2013). Performance of Chlorella vulgaris for the Removal of Ammonia-Nitrogen from Wastewater. Environ. Eng. Res.,18(4): 235-239.

Doumas, B. T.; Watson, W. A. and Biggs, H. G. (1971). Albumin standards and the measurement of serum albumin with bromcresol green. Clin. Chem. Acta, 31(1): 87-96. 
Ebeling, J. M.; Timmons, M. B. and Bisogni, J. J. (2006). Engineering analysis of the stoichiometry of photoautotrophic, autotrophic, and heterotrophic removal of ammonia-nitrogen in aquaculture systems. Aquaculture, 257: 346-358.

Ellefson, R. D. and Caraway, W. T. (1976). Fundamentals of clinical chemistry. In: TieztzNW, editor. SaundersWB, Philadelphia, USA.

Hanna, M. I.; El-Hady, M. A.; Ahmed, H. A.; Elmeadawy, S. A. and Kenwy, A. M. (2014). A contribution on Pseudomonas aeruginosa infection in African Catfish (Clarias garipinus). Research Journal of Pharmaceutical Biological and Chemical Sciences, 5:175-588.

Hargreaves, J. A. (2006). Photosynthetic suspended-growth systems in aquaculture. Aquacult. Eng., 4, 344-363.

Henry, R. J. (1974). Clinical Chemistry Principles and Techniques, 2nd ed. Harper and Row. Publ, New York, 525 P.

Ibrahim, S. A. and Mahmoud, S. A. (2005). Effect of heavy metals accumulation on enzyme activity and histology in liver of some Nile fish in Egypt. Egypt. J. Aquat. Biol. and Fish., 9(1): 203-219.

Kadry, S. M.; Tayel, S. I.; Afify, M. F. H. and El-Sayed, R. A. (2015). Ecohistopathological studied on Oreochromis niloticus fish living in Damietta Branch in Egypt. World J. Pharm. Sci., 3(5): 815-825.

Kim, J.; Lingaraju, B. P.; Rheaume, R.; Lee, J-Y. and Siddiqui, K. F. (2010). Removal of Ammonia from Wastewater Effluent by Chlorella Vulgaris. Tsinghua Science and Technology, 15(4): 391-396.

Kim, J.; Liu, Z.; Lee, J. Y. and Lu, T. (2013). Removal of nitrogen and phosphorus from municipal wastewater effluent using Chlorella vulgaris and its growth kinetics. Desalination and Water Treatment, 51: 7800 - 7806.

Lee, R. E. (2008). Phycology. $4^{\text {th }}$ Edition. Cambridge University Press, New York. $547 \mathrm{pp}$.

Moss S. M. (2002). Dietary importance of microbes and detritus in Penaeid shrimp aquaculture. In: Lee C.S., O'Bryen, P. (eds.) Microbial Approaches to Aquatic Nutrition within Environmentally Sound Aquaculture Production Systems, World Aquaculture Society, Baton Rouge, U.S.A.: 1-18.

Perez-Garcia, O.; Escalante, F. M. E.; De-Bashan, L. E. and Bashan, Y. (2011). Heterotrophic cultures of microalgae: Metabolism and potential products. Water Res., 45(1):11-36.

Prescott, A. G. (1978). Temperature and manganese as determining factor in the presence of Diatoms or blue-green algal flora in stream, Proceedings of The National Academy of Sciences, 64: 472-478.

Rapatsa, M. M. and Moyo, N. A. G. (2013). Hematological, histological and growth characteristics of Oreochromis mossambicus exposed to effective microorganisms in organically manured aquadams.Asian Journal of Animal veterinary Advances, 8(7): 852-862.

Reitman, S. and Frankel, S. (1957). A colorimetric method for the determination of serum glutamic oxaloacetic and glutamic pyruvate transaminase. Am. J. Clin. Pathol., 28:56.

Saad, S. M. M.; El-Deeb, A. E.; Tayel, S. I. and Ahmed, N. A. M. (2011). Haematological and histopathological studies on Clarias gariepinus in relation to water quality along Rosetta branch, River Nile, Egypt. J. Exp. Bio. (Zool.); 7(2): 223-233. 
Sanchez, I. A.; Bastos, R. K. X. and Lana, E. A. T. (2018). Tilapia rearing with high rate algal pond effluent: ammonia surface loading rates and stocking densities effects. Water Science and Technology, 78(1):49-56.

Schrader, K. K.; Green, B. W. and Perschbacher, P. W. (2011). Development of phytoplankton communities and common off-flavors in a biofloc technology system used for the culture of channel catfish Ictalurus punctatus. Aquaculture, 45:118-126.

Shalaby, E. A. (2011). Prospect of effective microorganism's technology in wastes treatment in Egypt. Asian Pacif . J. Trop. Biomed., 6:243-248.

Shawky, H. A.; Abdel Gwad, A. M.; Bayomi, A. M. and Abdel Mottaleb, M. S. A. (2015). Removal of Ammonia and Phosphate from Water Resources using Free and Immobilized Microalgae. International Journal of Environment, 4(3): 193203.

Stein, E.A., (1987). Lipids, lipoproteins and Apo lipoproteins. In: Tietz, N.W. (Ed.), Fundamentals of Clinical Chemistry. 3rd Edn., WB Saunders, Philadelphia, pp: 470-479.

Su, Y.; Mennerich, A. and Urban, B. (2012). Coupled nutrient removal and biomass production with mixed algal culture: Impact of biotic and abiotic factors. Bioresource Technology, 118: 469-476.

Tayel, S. I.; Mahmoud, S. A.; Ahmed, N. A. M. and Abdel Rahman A. S. A. (2018). Pathological impacts of environmental toxins on Oreochromis niloticus fish inhabiting the water of Damietta branch of the River Nile, Egypt. Egyptian Journal of Aquatic Biology, 22 (5): 309- 321

Tayel, S. I.; Ahmed, N. A. M. and EL-Hossiny, M. A. (2014). Impact of diffused pollution on histological and hematological properties of Mugilcephalus and Mugilcapito collected from lake Manzalah, Egypt. Int. J. Environ. Sci. Engineer., 5: 51-67.

Tietz, N.W. (1990). Clinical guide to laboratory tests, $2^{\text {nd }}$ edition, (Saunders, W.B., Ed.), Philadelphia, USA, 566pp.

Tietz, N.W. (1995). Clinical guide to laboratory tests, $3^{\text {rd }}$ edition, (Saunders, W.B., Ed.), Phila.

Widanarni; Ekasari, J. and Maryam, S. (2012). Evaluation of Biofloc Technology Application on Water Quality and Production Performance of Red Tilapia Oreochromis sp. Cultured at Different Stocking Densities. HAYATI Journal of Biosciences, 19(2): 73-80.

Yacoub, A. M.; Mahmoud, S. A. and Tayel, S. I. (2008). Health status of Oreochromis niloticus in fish farm irrigated with drainage water in El-Fayoum Province. Egypt. J. Aquat. Res., 34(1): 161-175.

Younes, A. M.; Laila, A. M.; Eida, M. F. and Gaafer, A.Y. (2015). Characterization and pathogen challenge of Pseudomonas species from Oreochromis niloticus in Egypt. Research Journal of Pharmaceutical, Biological and Chemical Sciences, 6:312-317.

Zhu, L.; Wang, Z.; Shu, Q.; Takala, J.; Hiltunen, E.; Feng, P. and Yuan, Z. (2013). Nutrient removal and biodiesel production by integration of freshwater algae cultivation with piggery wastewater treatment. Water Research, 47: 4294-4302.

Zita, A and Hermansson, M. (1994). Effects of ionic-strength on bacterial adhesion and stability of flocs in a waste-water activated sludge system. App Environ Microbiol., 60:3041-3048. 


\section{ARABIC SUMMARY}

\section{المعالجة البيولوجية للأمونيا بإستخدام نظام البيوفلوك لأسماك البطى النيلى}

نصر أحمد محمد أحمد، ناصر سليمان فليفل، صفاء إسماعيل طايل، سعاد أحمد محمود، عبدالغتى سليمان

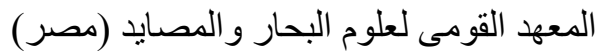

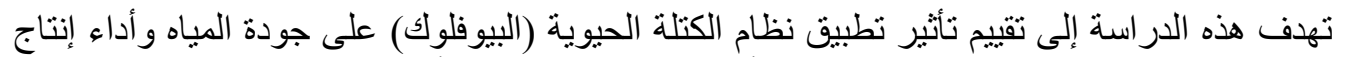

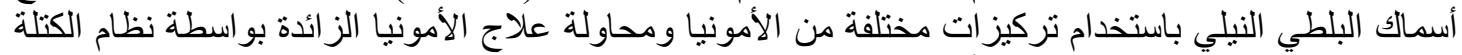

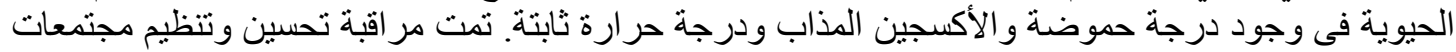

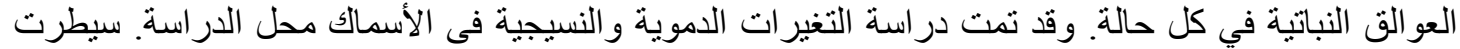

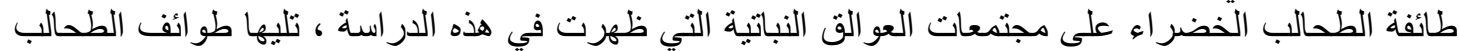
الخضر اء المزرقة و الدياتومات و الطحالب اليوجلينية.

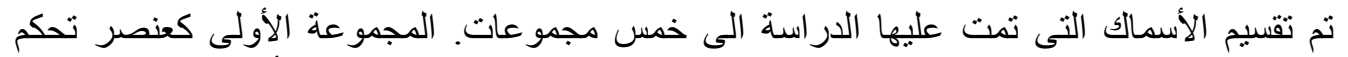

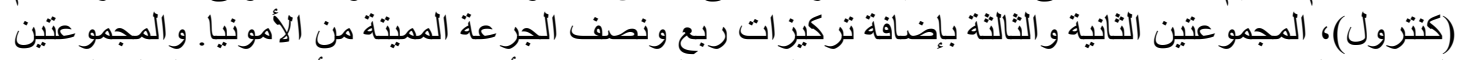

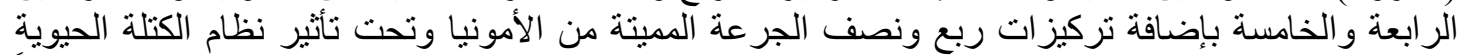

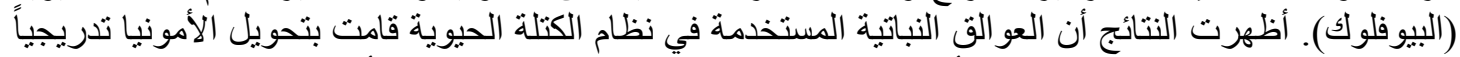

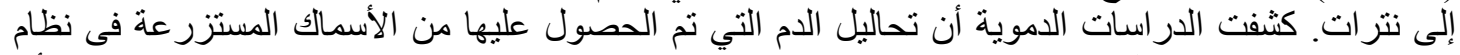

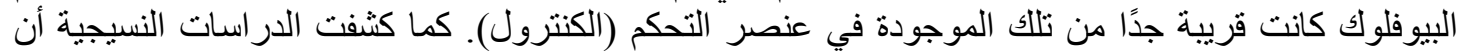

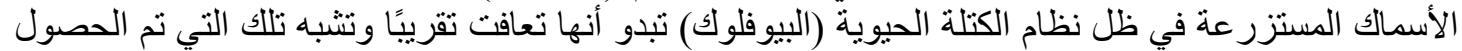

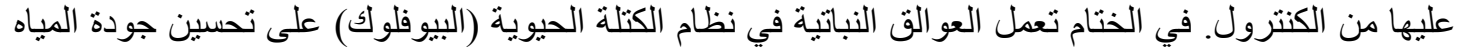

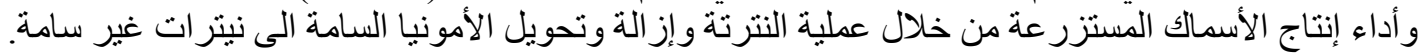

